\title{
The Potential of Some Non-Conventional Vegetable Oils in Biodiesel Applications
}

Abolanle Saheed Adekunle ${ }^{1 *}$, John Adekunle Oyedele Oyekunle ${ }^{1 *}$, Basirat Adeola Tijani ${ }^{1}$, Wasiu Oladotun Makinde ${ }^{2}$, Olaoluwa Ruth Obisesan ${ }^{1}$, Muibat Olabisi Bello ${ }^{3}$, Iyabo Oluremi Olabanji $^{1}$, Ojo Oluwaseyi Samson ${ }^{1}$

${ }^{1}$ Department of Chemistry, Obafemi Awolowo University, Ile-Ife, Nigeria sadekpreto@gmail.com, oyekunle@oauife.edu.ng,Barshty1988@yahoo.com, obisesan.olaoluwa@gmail.com, ioolabanji@yahoo.com,ojooluwaseyi_s@yahoo.com

${ }^{2}$ Centre for Energy Research and Development Obafemi Awolowo University, Ile-Ife, Nigeria. dotmark4great@yahoo.co.uk

${ }^{3}$ Department of Pure and Applied Chemistry, Ladoke Akintola University of Technology, P.M.B. 4000, Ogbomoso, Oyo State, Nigeria mobello274@gmail.com

\begin{abstract}
This work studied the potentials of some non-conventional oils biodiesel as an alternative to biodiesel made from a conventional seed oil (palm kernel oil), and petroleum-based diesel. The fruits of three non-conventional oilseeds, namely: Persea Americana (Avocado pear), Irvingia gabonenses (Dica nut) and Darcryodes edulis (Native pear) were obtained from local markets in Ile-Ife, Osun State Nigeria while petroleum-based diesel (PBD) used for comparative study was obtained commercially. The outer fleshy layers of the fruits were separated from the seeds while both were air-dried for some days and later milled. The oils extracted from the milled samples were esterified to produce biodiesel using methanol in the presence of $\mathrm{NaOH}$ as catalyst. The biodiesels were analyzed for their fuel properties using standard methods. Results showed that the biodiesel yield of Irvingia gabonensis oil diesel (IGOD), Darcryodes edulis oil diesel (DEOD) and Persia americana oil diesel (PAOD) were 94\%, 82\% and 96\% respectively. These values compared favourably with that of palm kernel oil diesel (PKOD) (91\%) produced under same conditions, and with the literature standard yield of $96.5 \%$ set for biodiesel. The pour points of PKOD, PAOD and DEOD were $3,-6$ and $1{ }^{\circ} \mathrm{C}$, respectively, with PAOD pour point very close to that of $\operatorname{PBD}\left(\geq-10^{\circ} \mathrm{C}\right)$ obtained under similar experimental conditions. Except for IGOD, all the oils have pour points within the standard range of -15 to $16^{\circ} \mathrm{C}$ set for biodiesel suggesting the suitability of the oils for biodiesel applications. The iodine values of the biodiesel ranged between 9.64 and $16.52 \mathrm{meq} / \mathrm{kg}$ and agreed closely with 12 - $18 \mathrm{meq} / \mathrm{kg}$ reported in literature for PKOD. The biodiesel blend with PBD in the ratio 10:90, 20:80, 30:70 and 40:60 demonstrated improved physico-chemical properties (including smoke point, flash point, cloud point, pour point, density, viscosity and acid value) that could meet the fluidity requirements for biodiesel applications.
\end{abstract}

Indexing terms/Keywords:-Non-Conventional oils; Biodiesel; Physico-chemical properties; Petroleum diesel.

\section{Academic Discipline And Sub-Disciplines}

Analytical/Environmental Chemistry

\section{SUBJECT CLASSIFICATION}

Vegetable Oils in Biodiesel Applications

\section{TYPE (METHOD/APPROACH)}

Oil extraction, transesterification, biodiesel yield determination, physico-chemical parameters analysis.

\section{Council for Innovative Research}

Peer Review Research Publishing System

\section{Journal: Journal of Advances in Chemistry}

Vol. 11, No. 9

www.cirjac.com

editorjaconline@gmail.com, editor@cirjac.com 


\subsection{INTRODUCTION}

Climate change is currently a serious global environmental concern. Conferences upon conference have been held by various stakeholders on the way to arrest the phenomenon. Anthropogenic factors have been identified as the main cause of global warming, which is responsible for the adverse change in climate due to continuous emission of greenhouse gases $\left(\mathrm{CH}_{4}, \mathrm{CO}_{2}, \mathrm{NOx}\right)$ into the atmosphere from burning of fossil fuel (mainly from petroleum) [1-3].

However, world energy demand is increasing geometrically as evidenced in increased need of fuel for transportation, industrial as well as domestic operations. Hence, the war against climate change and its attendant environmental pollution and global warming resulting from the use of petroleum fuels remains unsuccessful [4].

Biodiesel is a non-petroleum based fuel that consists of mixture of alkyl esters derived from either the transesterification of triglycerides (TGs) or the esterification of free fatty acid (FFAs) with low molecular weight alcohol. Biodiesel can be used in conventional compression ignition-engines, which need almost no modification. Biodiesel can also be used as heating oil and as fuel $[5,6]$. The flow and combustion properties of biodiesels are similar to petroleum based diesel and thus can be used either as substitute for diesel fuel or more commonly in fuel blend. Modern biofuels have been reported as a promising long term renewable energy source which has potential to address both environmental impacts and security concerns posed by current dependence on fossil fuels [7-9].

Considering the rate at which the world petroleum-based energy demand is increasing as well as the decrease in world's reserve of petroleum, it has been widely reported that not less than ten major oil fields from the twenty largest world oil producers are already experiencing decline in oil reserve [10]. Recently published data also revealed a total of 29 major oil producing countries already experiencing declining oil reserves from the years 2005-2007 [10]. Thus, it has become imperative to source for an alternative renewable fuel such as biodiesel from non-conventional seed oils and other agricultural waste products $[3,11,12]$.

The fruits and seeds from which the non-conventional oils are obtained are available in large quantities but remain either underexploited or unexploited and are allowed to waste due to poor storage system and delay in converting them into important uses for economic gains as it is done for sunflower oil, groundnut oil, soybean oil, etc. Previous studies [13] had shown that these non-conventional oils possessed certain physico-chemical properties that suggest their use either for edibility or industrial applications. To the best of our knowledge, there is paucity of literature on the physical and chemical properties of the resultant biodiesels obtained from the crude and refined forms of these oils. This therefore brought about the motivation of the present study to determine the physico-chemical properties of biodiesels made from the nonconventional oils and highlight the possible benefits of such biodiesels on a large scale basis. The study also compares the biodiesel properties of the non-conventional oils with that of palm kernel oil (conventional seed oil) and commercially available petroleum-based diesel. The blend properties of the biodiesel and petroleum-based diesel were also studied and discussed.

\subsection{MATERIALS AND REAGENTS}

Matured fruits of Persea americana (Avocado pear), Irvingia gabonenses (Dica nut) and Darcryodes edulis (Native pear) and palm kernel seed used in this work were obtained from local markets in lle-lfe, Osun State, Nigeria. Commercially available petroleum-based diesel (Diesel motor oil SAE 40 API CF/SF manufactured in Nigeria by African Petroleum PLC) was also obtained for comparative experiments. Other materials include agate mortar and pestle, a batch reactor (500 $\mathrm{mL}$ round bottom flask), mechanical stirrer, magnetic stirrer, $120 \mathrm{~mL}$ plastic bottle; $100 \mathrm{~mL}$ beakers; Metler electronic balance; n-hexane; water bath; $\mathrm{NaOH}$; Wheaton soxhlet extractor; and $99.5 \%$ methanol.

\subsection{Oil Extraction and Biodiesel Production}

Fruits of Persea americana (PA), Dacryodes edulis (DE) and Irvingia gabonensis (IG) collected for the experiments were washed, and the flesh separated from the seeds. Both the flesh and the seeds were air dried and later oven dried at $50^{\circ} \mathrm{C}$ for 3 hours. From a previous study by Akanni et al. [13], the oil contents of $50.14,5.13,58.09,17.28$ and $70.41 \%$ were reported for PA flesh, PA seed, DE flesh, DE seed and IG seed, respectively. Thus, the present study was focused on oils extracted from PA flesh, DE flesh and IG seed because of their respective high percentage oil composition. The dried flesh and seeds were pulverized using a mechanical grinder. Oil was extracted from the milled sample using $n$-hexane according to the methods of the Association of Official Analytical Chemists [14]. The extracted oils were represented as PAO, DEO and IGO for Persea americana oil, Dacryodes edulis oil and lirvingia gabonensis oil, respectively. Palm kernel oil (PKO) was extracted under the same condition to serve as a control and for comparative study. The extracted oil was stored in a sealed plastic bottle for further study.

Biodiesel was produced from the extracted oils and the commercially obtained palm kernel oil using methanol in the presence of $\mathrm{NaOH}$ as catalyst following the method already described in literature [15-17]. The transesterification reactions were carried out batch wise at a $6: 1$ methanol to oil molar ratio, $1 \%$ catalyst to oil and $65^{\circ} \mathrm{C}$ reaction temperatures. These variables were chosen since they have been found to give optimal yields of methyl ester from seed oils [18]. A batch reactor $(500 \mathrm{~mL})$ was charged with $240 \mathrm{~g}$ palm kernel oil and heated to the desired temperature in a water bath. Accurately weighed $40 \mathrm{~g}$ methanol and optimal weight of $\mathrm{NaOH}$ ( $1 \%$ by weight of oil) were mixed and heated in a separate container to the desired temperature before being added to the reactor contents. The mechanical stirrer at a stirring speed of $400 \mathrm{rpm}$ was started immediately the mixture was added to the batch reactor. The reactions were performed for 4 hours, and afterwards the reactor and its contents were cooled down under convective air current. The 
separation of the fatty acid methyl ester (FAME) and the glycerine phase was carried out by means of a separating funnel. The percentage conversion of the different oils to biodiesel was calculated as:

$\%$ conversion $=\frac{\text { Mass of biodiesel produced }}{\text { Mass of oil used }} \times 100$

The biodiesel obtained are represented as Palm kernel oil diesel (PKOD), Irvingia gabonensis oil diesel (IGOD), Dacyodes edulis oil diesel (DEOD) and Persia Americana oil diesel (PAOD). A commercially available petroleum based biodiesel (PBD) was used for comparative study.

\subsection{Physico-chemical Properties of the Biodiesel}

The physico-chemical properties of the biodiesels were determined using the standard methods of the Association of Official Analytical Chemists [14]. Parameters analyzed were relative density, kinematic viscosity, surface tension, cloud point, smoke point, acid value (AV), \% free fatty acid (\%FFA) and iodine value (IV). The density and viscosity at $30 \mathrm{oC}$, $400 \mathrm{C}$ and $60 \mathrm{oC}$ were measured using a $25 \mathrm{~mL}$ specific gravity bottle and a $50 \mathrm{~mL}$ PSL ASTM-IP viscometer. The smoke, flash, cloud and pour points were determined using the American Society for Test and Material (ASTM) standard methods as described by Salvatore (2003) [19].

\subsection{RESULTS AND DISCUSSION}

The results of the biodiesel analyses compared with that of petroleum based biodiesel (PBD) are presented in Tables $1-4$. The biodiesel yield obtained (Table 1) for PKO (91\%), IGO (94\%), and PAO (96\%), compared favourably with $96.5 \%$ set by the International Standards (American Society for Test and Material - ASTM 900 and European Norm - EN 14214), while the $82 \%$ yield obtained for DEO agreed closely with the set standard. The percentage biodiesel yield obtained was favourable suggesting low free fatty acid (FFA) content of the oils. It has been observed that the amount of FFA contents of oil greatly determine the conversion of crude vegetable oils into biodiesel, hence the conversion efficiency decreases considerably if FFA content is greater than 3\% [20]. Earlier, Akanni et al. [13] had reported acid values of 2.607,6.10 and $6.726 \mathrm{mgKOH} / \mathrm{g}$ sample, corresponding to \%FFA of $1.31,3.07$ and $3.38 \%$ for IGO, PAO and DEO, respectively. These values are within the $3 \%$ expected for crude vegetable oils that would produce very high biodiesel yield as obtained in this work.

Table 1.0: Physico-Chemical Properties of Biodiesel Produced from Oil Seeds

\begin{tabular}{|c|c|c|c|c|c|c|}
\hline Properties & PKOD & IGOD & DEOD & PAOD & PBD & Reference \\
\hline $\begin{array}{l}\% \\
\text { Biodiesel } \\
\text { yield }\end{array}$ & $91 \% \pm 4.250$ & $94 \% \pm 5.550$ & $82 \% \pm 2.250$ & $96 \% \pm 6.000$ & & - \\
\hline $\begin{array}{l}\text { Cloud } \\
\text { Point }\end{array}$ & $6^{0} \mathrm{C} \pm 0.500$ & $31^{0} \mathrm{C} \pm 1.000$ & $4^{0} \mathrm{C} \pm 0.800$ & $3^{0} \mathrm{C} \pm 0.250$ & $-8^{0} \mathrm{C} \pm 1.000$ & -3 to $12^{a}$ \\
\hline Pour Point & $3^{0} \mathrm{C} \pm 0.200$ & $29^{0} \mathrm{C} \pm 2.000$ & $1^{0} \mathrm{C} \pm 0.100$ & $-6^{0} \mathrm{C} \pm 0.100$ & $\geq-10^{0} \mathrm{C} \pm 0.000$ & -15 to $16^{a}$ \\
\hline $\begin{array}{l}\text { Smoke } \\
\text { Point }\end{array}$ & $110^{\circ} \mathrm{C} \pm 9.000$ & $102^{0} \mathrm{C} \pm 3.500$ & $90^{\circ} \mathrm{C} \pm 5.000$ & $105^{0} \mathrm{C} \pm 8.000$ & $60^{\circ} \mathrm{C} \pm 5.000$ & \\
\hline $\begin{array}{l}\text { Flash } \\
\text { Point }\end{array}$ & $150^{\circ} \mathrm{C} \pm 3.000$ & $165^{\circ} \mathrm{C} \pm 5.000$ & $98^{0} \mathrm{C} \pm 5.000$ & $180^{\circ} \mathrm{C} \pm 10.000$ & $70^{0} \mathrm{C} \pm 5.000$ & $100-170^{a}$ \\
\hline $\begin{array}{l}\text { Surface } \\
\text { Tension }\end{array}$ & $0.0388 \pm 0.000$ & $0.0395 \pm 0.000$ & $0.0364 \pm 0.000$ & $0.0387 \pm 0.000$ & $0.0372 \pm 0.000$ & \\
\hline Acid Value & $0.935 \pm 0.000$ & $1.015 \pm 0.000$ & $2.170 \pm 0.000$ & $2.230 \pm 0.000$ & $1.980 \pm 0.000$ & \\
\hline
\end{tabular}


(mgKOH/g)

\begin{tabular}{lccccc}
$\%$ FFA & $0.469 \pm 0.000$ & $0.510 \pm 0.000$ & $1.087 \pm 0.000$ & $1.120 \pm 0.000$ & $0.993 \pm 0.000$ \\
$\begin{array}{l}\text { lodine } \\
\text { Value } \\
\text { (meq/Kg) }\end{array}$ & $16.52 \pm 0.721$ & $10.07 \pm 0.470$ & $9.64 \pm 0.500$ & $16.00 \pm 0.554$ & $15.00 \pm 0.229$ \\
\hline
\end{tabular}

\section{a: Biodiesel standard, American Society For Test And Materials (ASTM D6751, 2008)}

The acid values obtained in this study for the biodiesels are within the range $0.935-2.230 \mathrm{mgKOH} / \mathrm{g}$, while the \%FFA ranged from $0.46 \%$ in PKOD to $1.120 \%$ in PAOD (Table 1). The decrease in both the acid value and the \%FFA of the biodiesel relative to that of their crude vegetable oils further confirmed the successful modification of the free fatty acids in the raw oils to the fatty esters in their respective biodiesel. Similarly, the acid and the \%FFA values for commercially available PBD analyzed under the same conditions were 1.980 and $0.993 \%$ respectively. Palm kernel oil diesel (PKOD) and IGOD had approximately half these values, while the acid values and \%FFA of PAOD and DEOD agreed closely with that of PBD. This implies that the \%FFA and acid values of the nonconventional oils biodiesels produced met the minimum requirements for their potential applications as source of fuel.

The iodine value ranged between $9.64 \mathrm{meq} / \mathrm{kg}$ for DEOD and $16.52 \mathrm{meq} / \mathrm{kg}$ for PKOD (Table 1). The values obtained for PAOD, PKOD agreed with $15.00 \mathrm{meq} / \mathrm{kg}$ obtained for PBD under the same condition, and $12-18 \mathrm{meq} / \mathrm{kg}$ reported in literature for palm kernel biodiesel [21]. The 9.64 and $10.07 \mathrm{meq} / \mathrm{kg}$ recorded for DEOD and IGOD respectively were closer to $12 \mathrm{meq} / \mathrm{kg}$ for PKD reported in literature (Mittelbach and Schober, 2008). Therefore, the results obtained in this study showed that the produced biodiesel could favourably compete with PKOD and PBD as alternative fuel material for energy generation. High iodine values of biodiesel have been associated with fuel polymerization and formation of deposit in heated internal combustion engine. It has also been linked with decreased oxidation stability that could lead to degradation products or deterioration of the lubricating property, and some inhibition of engine operation [22].

The pour and cloud points analyses in the characterization of biodiesel is very important for they determine the suitability of the fuel for large storage and pipeline distribution [23]. Pour point is the lowest temperature at which the fuel can still be moved, before it becomes gelled. The cloud point on the other hand is the temperature at which small solid crystals are first visually observed as the fuel is cooled. The cloud and pour points of the produced biodiesel were found to be higher than that of PBD (Table 1). The difference in value was more significant for IGOD (cloud point $31^{\circ} \mathrm{C}$; pour point $29^{\circ} \mathrm{C}$ ). Palm kernel oil diesel (PKOD), PAOD and DEOD had values close to that of PBD, with PAOD pour point $\left(-6^{\circ} \mathrm{C}\right)$ occurring very close to that of PBD $\left(\geq-10^{\circ} \mathrm{C}\right)$. However, the higher cloud and pour points of IGOD might be due to the high fatty acid content of its oil since higher proportions of saturated fatty acids accounts for higher pour point of biodiesel [24]. These properties of IGOD could limit its application as fuel in diesel engine except the oil is improved upon by refining processes. The result therefore suggests that PKOD, DEOD and PAOD can be potential materials in biofuel applications, while IGOD needs further processing before it can be suitable for similar applications.

It is evident from Table 1 that the flash points of PKOD $\left(150{ }^{\circ} \mathrm{C}\right)$, IGOD $\left(165{ }^{\circ} \mathrm{C}\right)$, DEOD $\left(98{ }^{\circ} \mathrm{C}\right)$ and PAOD $\left(180{ }^{\circ} \mathrm{C}\right)$ respectively were higher than that of petroleum-based diesel $\left(70^{\circ} \mathrm{C}\right)$. Similar trend was observed for the smoke point values (Table 1). Flash point determines the safety of fuel during its handling and storage. It is the lowest temperature at which the vapours above the fuel become flammable. The flash point, therefore, specifies the temperature to which a fuel needs to be heated for spontaneous ignition of the vapour and air above the fuel to occur [24]. The results in this work agreed with that of other workers on biodiesel produced from various oil-bearing seeds as well as domestic waste vegetable oil where it was reported that biodiesel has a flash point that is considerably higher than petroleum-based diesel $[24,20]$. This means that the fire hazard associated with transportation, storage and utilization of biodiesel produced from the non-conventional oils in this study is much less than that of petroleum-based diesel.

Table 2 presents the physico-chemical properties of the biodiesel used in this study when blended with the petroleumbased diesel (PBD) at different biodiesel/PBD ratio. This experiment was limited to PAOD and DEOD since I. gabonensis oil congeal readily at room temperature and its biodiesel applications could be limited because of IGOD high cloud and pour points respectively. On the other hand, PKOD blend with petroleum diesel had been studied and reported to impact positively on its bio fuel properties [25].

Table 2.0: Physico-Chemical Properties of Biodiesels Blend with Petroleum-Based Diesel

$\begin{array}{llllllll}\begin{array}{l}\text { Cloud } \\ \text { pt }\end{array} & \begin{array}{l}\text { Pour } \\ \text { pt }\end{array} & \begin{array}{l}\text { Smoke } \\ \text { pt }\end{array} & \begin{array}{l}\text { Flash } \\ \text { pt }\end{array} & \begin{array}{l}\text { Surface } \\ \text { Tension }\end{array} & \begin{array}{l}\text { Acids Value } \\ (\mathrm{mgKOH} / \mathrm{g})\end{array} & \% \text { FFA } & \begin{array}{l}\text { lodine Value } \\ (\mathrm{meq} / \mathrm{Kg})\end{array}\end{array}$


PAOD

$3^{0} \mathrm{C}$

$-9^{\circ} \mathrm{C} \quad 70^{\circ} \mathrm{C}$

$80^{\circ} \mathrm{C}$

$213 \pm 2.517$

$1.255 \pm 0.249$

$0.631 \pm 0.125 \quad 13.5 \pm 0.326$

10:90

PAOD $-8^{\circ} \mathrm{C} \quad 70^{\circ} \mathrm{C}$

$85^{\circ} \mathrm{C}$

$220 \pm 1.528$

$1.670 \pm 0.040$

$0.839 \pm 0.209$

$16.0 \pm 0.236$

$20: 80$

PAOD

$30: 70$

$2^{0} \mathrm{C} \quad-9^{0} \mathrm{C} \quad 70^{\circ} \mathrm{C}$

$80^{\circ} \mathrm{C}$

$209 \pm 3.000$

$1.852 \pm 0.266$

$1.508 \pm 0.682$

$15.3 \pm 0.395$

PAOD $\quad 2^{0} \mathrm{C} \quad-8^{\circ} \mathrm{C} \quad 65^{\circ} \mathrm{C}$

$80^{\circ} \mathrm{C}$

$215 \pm 4.583$

$1.543 \pm 0.198$

$0.776 \pm 0.100$

$12.4 \pm 0.208$

$40: 60$

\begin{tabular}{|c|c|c|c|c|c|c|c|c|}
\hline $\begin{array}{l}\text { DEOD } \\
10: 90\end{array}$ & $2^{0} \mathrm{C}$ & $-3^{0} \mathrm{C}$ & $90^{\circ} \mathrm{C}$ & $95^{\circ} \mathrm{C}$ & $208 \pm 11.135$ & $1.824 \pm 0.199$ & $0.917 \pm 0.100$ & $9.2 \pm 0.210$ \\
\hline $\begin{array}{l}\text { DEOD } \\
20: 80\end{array}$ & $3^{0} \mathrm{C}$ & $-2^{0} \mathrm{C}$ & $60^{\circ} \mathrm{C}$ & $90^{\circ} \mathrm{C}$ & $213 \pm 7.638$ & $1.616 \pm 0.302$ & $0.812 \pm 0.151$ & $10.6 \pm 0.318$ \\
\hline $\begin{array}{l}\text { DEOD } \\
30: 70\end{array}$ & $2^{0} \mathrm{C}$ & $-7^{0} \mathrm{C}$ & $70^{\circ} \mathrm{C}$ & $80^{\circ} \mathrm{C}$ & $208 \pm 1.155$ & $1.788 \pm 0.194$ & $0.898 \pm 0.098$ & $11.8 \pm 0.801$ \\
\hline $\begin{array}{l}\text { DEOD } \\
40: 60\end{array}$ & $4^{0} \mathrm{C}$ & $-8^{0} \mathrm{C}$ & $90^{\circ} \mathrm{C}$ & $65^{\circ} \mathrm{C}$ & $200 \pm 3.000$ & $2.308 \pm 0.379$ & $1.160 \pm 0.190$ & \\
\hline
\end{tabular}

From Table 2, PAOD and DEOD blend with PBD in the ratio 10:90, 20:80, 30:70 and 40:60, led to improved physicochemical properties that met the fluidity requirements for biodiesel applications. For example, PAOD and DEOD with initial cloud points of 3 and $4{ }^{\circ} \mathrm{C}$ respectively (Table 1) had their cloud points reduced to $2{ }^{\circ} \mathrm{C}$ at blend ratio of $30: 70$. Similarly, their pour points which are initially -6 and $1{ }^{\circ} \mathrm{C}$ respectively have now become $-8{ }^{\circ} \mathrm{C}$ at the blend ratio of $40: 60$. Persia americana oil diesel (PAOD) and DEOD flash points which were initially 180 and $98{ }^{\circ} \mathrm{C}$ (Table 1) got reduced to 80 and 90 ${ }^{\circ} \mathrm{C}$ respectively at the blend ratio 40:60 (Table 2). In the same vein, PAOD and DEOD smoke points which were initially 105 and $90{ }^{\circ} \mathrm{C}$ (Table 1), had their smoke points reduced to $65^{\circ} \mathrm{C}$ at the blend ratio 40:60 (Table 2). The improved values of cloud, pour, flash and smoke points of the biodiesels due to their blend with PBD is represented pictorially in Figures 1 and 2 below. 


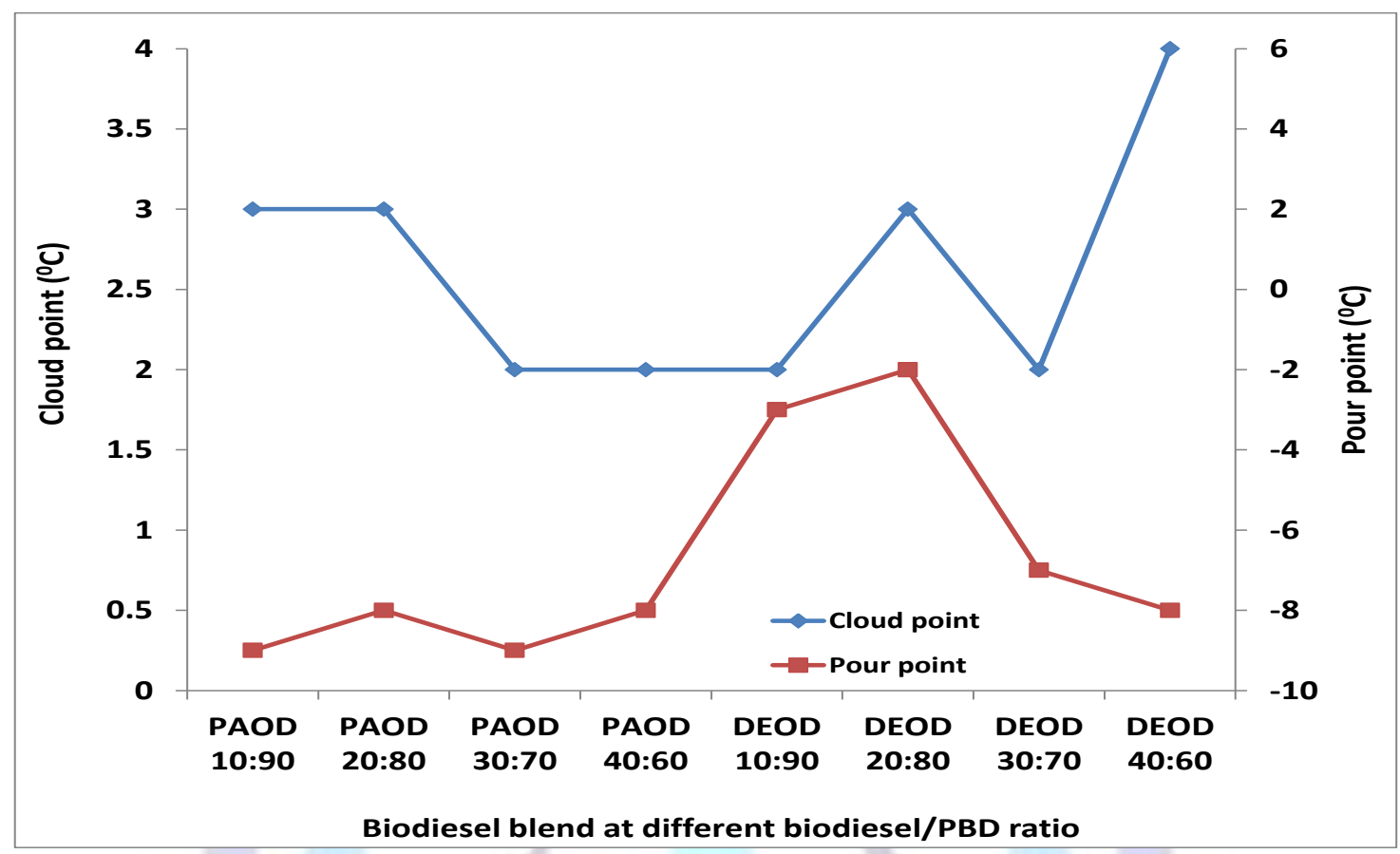

Figure 1: Pour point $\left({ }^{\circ} \mathrm{C}\right)$ and cloud point $\left({ }^{\circ} \mathrm{C}\right)$ values for biodiesel blend with petroleum-based diesel(PBD)at different biodiesel/PBD ratio.

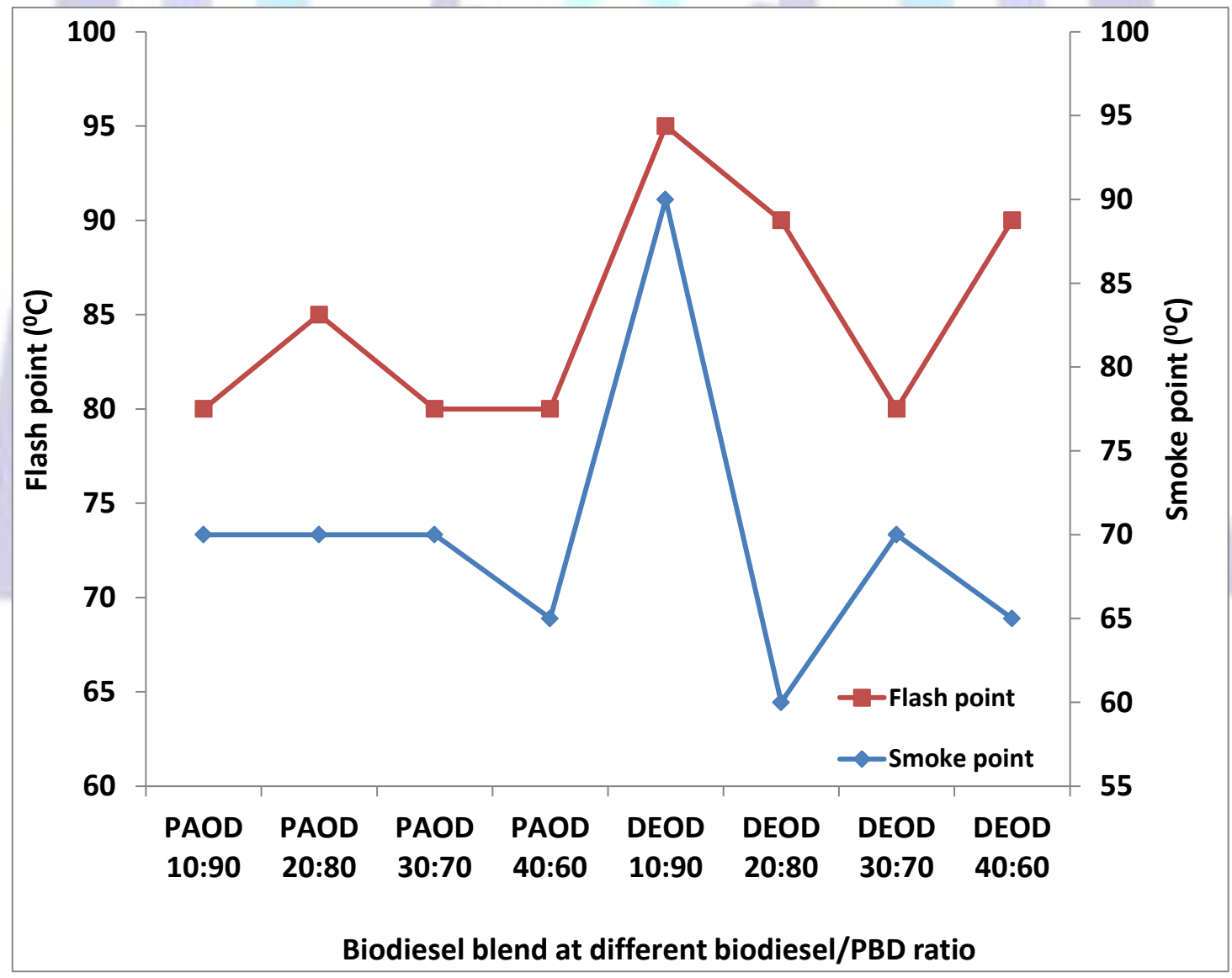

Figure 2: Smoke point $\left({ }^{\circ} \mathrm{C}\right)$ and flash point $\left({ }^{\circ} \mathrm{C}\right)$ values for biodiesel blend with petroleum-based diesel(PBD) at different biodiesel/PBD ratio.

Similar trend was observed for the chemical parameters of the biodiesels in their blends with PBD. For example, PAOD and DEOD acid values which are initially 2.230 and $2.170 \mathrm{mgKOH} / \mathrm{g}$ are now reduced to 1.255 and $1.824 \mathrm{mgKOH} / \mathrm{g}$ respectively at blend ratio 10:90 with PBD. Lower acid values were obtained at other blend ratio studied. Lower values were also obtained for the \%FFA due to the biodiesel blend with PBD (Table 2, Fig. 3). The iodine value dropped for 
PAOD from $16.0 \mathrm{meq} / \mathrm{Kg}$ to its lowest value $(12.4 \mathrm{meq} / \mathrm{Kg})$ at 40:60 blends, while no significant change was observed for the iodine value of DEOD at all the blend ratio studied.

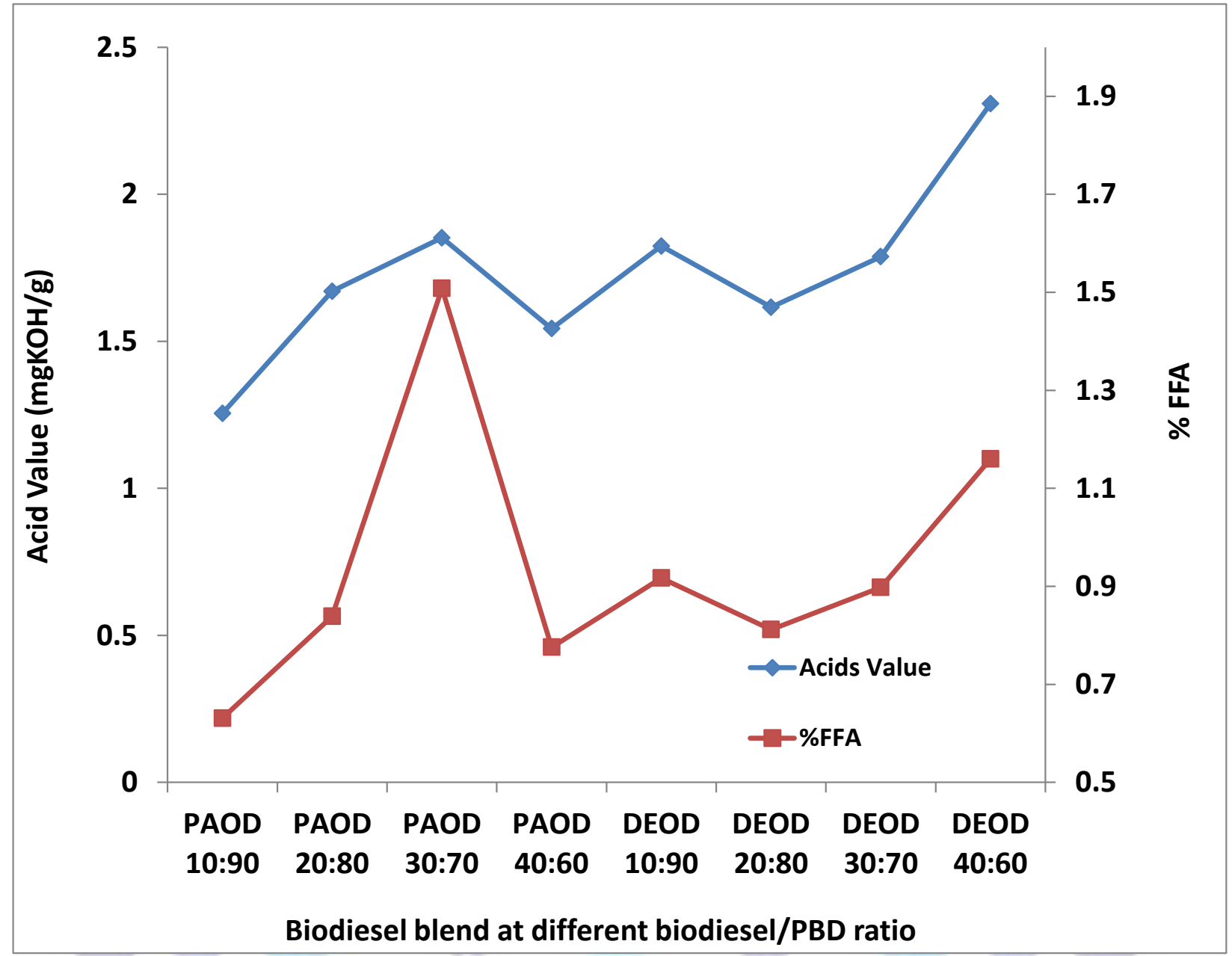

Figure 3: Acid values (mgKOH/g) and \% free fatty acid (FFA) values for biodiesel blend with petroleum-based diesel(PBD) at different biodiesel/PBD ratio.

The economic implication of this result lies in the fact that the fuel potential of these biodiesels can be complemented with that of petroleum base diesels thereby reducing the present over dependence and high cost of purchasing petroleum based diesel.

Tables 3 and 4 present the effects of temperatures on the density and viscosity of the biodiesels and their blends. Density has been described as one of the most important parameters of fuel since certain performance indicators like heating value and cetane number are correlated with it $[20,26,27]$. At $30^{\circ} \mathrm{C}$, all the biodiesels used in this study had density values higher than that of the PBD $\left(0.850 \mathrm{~g} / \mathrm{cm}^{3}\right)$ under the same experimental conditions (Table 3), and $0.850 \mathrm{~g} / \mathrm{cm}^{3} \mathrm{standard}$ set for petroleum based diesel [28]. The implication of the high density of the biodiesel is that there will be delivery of a slightly greater mass of fuel especially for fuel injection equipment that operates on a volume metering system [29]. However, the density values for the biodiesel decreases with increase in temperature (Table 3).

Table 3: Effects of Temperature on Density and Viscosity of Biodiesel Produced from oil-seeds

\begin{tabular}{lllll}
\hline Biodiesel & $30^{\circ} \mathrm{C}$ & $40^{\circ} \mathrm{C}$ & $60^{\circ} \mathrm{C}$ & Reference
\end{tabular}

\begin{tabular}{llll}
\hline & \multicolumn{3}{c}{ Density $\left(\mathbf{g} / \mathbf{c m}^{3}\right)$} \\
\hline IGOD & $0.900 \pm 0.002$ & $0.897 \pm 0.000$ & $0.890 \pm 0.002$ \\
PAOD & $1.105 \pm 0.000$ & $1.103 \pm 0.001$ & $1.102 \pm 0.001$ \\
DEOD & $0.860 \pm 0.001$ & $0.853 \pm 0.000$ & $0.849 \pm 0.0001$ \\
PKOD & $0.880 \pm 0.001$ & $0.877 \pm 0.001$ & $0.872 \pm 0.001$
\end{tabular}




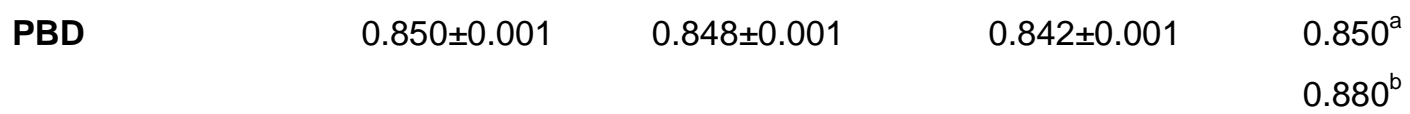

\section{Viscosity $\left(\mathrm{mm}^{2} / \mathrm{s}\right)$}

$\begin{array}{llll}\text { IGOD } & - & 19.46 \pm 0.001 & 10.19 \pm 0.001 \\ \text { PAOD } & 12.71 \pm 0.000 & 8.51 \pm 0.002 & 4.53 \pm 0.001 \\ \text { DEOD } & 5.59 \pm 0.001 & 4.30 \pm 0.000 & 3.48 \pm 0.000 \\ \text { PKOD } & 13.24 \pm 0.000 & 7.57 \pm 0.000 & 6.56 \pm 0.001 \\ \text { PBD } & 4.03 \pm 0.000 & 2.62 \pm 0.001 & 1.96 \pm 0.001\end{array}$

\section{$1.9-4.1^{\mathrm{a}}$ \\ $1.9-6.0^{b}$}

\footnotetext{
${ }^{a}$ Petroleum-based diesel standard, American Society For Test And Materials Standard(ASTM D975, 2008)

${ }^{b}$ Biodiesel standard, American Society For Test And Materials (ASTM D6751, 2008)
}

Effect of temperature on the viscosity of the biodiesel is presented in Table 3 . The viscosity values range from 5.59 to $12.71 \mathrm{~mm}^{2} / \mathrm{s}$. The viscosity of IGOD cannot be determined at room temperature because of the congealed nature of the oil. The viscosities values obtained in this work are too high compared with that of the PBD $\left(4.03 \mathrm{~mm}^{2} / \mathrm{s}\right)$ obtained under the same experimental conditions. Darcryodes edulis oil diesel (DEOD) viscosity value of $5.59 \mathrm{~mm}^{2} / \mathrm{s}$ fell within the ASTM standards $\left(1.9-6.0 \mathrm{~mm}^{2} / \mathrm{s}\right)$ for biodiesel [30]. Viscosity is a measure of the internal flow resistance of a liquid. Viscosity affects injection lubrication and fuel atomization [20]. High viscosity fuel has the tendency of forming engine deposits. Although high kinematic viscosity biodiesel when used in engines can help to lubricate the engine parts which may be an advantage to users [31], but the disadvantages also need to be carefully weighed.

In order to take care of the limitation due to the high density and viscosity of the biodiesel recorded in this work, the density and the viscosity of their blends at different ratios with PBD was carried out at different biodiesel/PBD ratios $(10: 90,20: 80,30: 70$ and 40:60), and the result is presented in Table 4.

Table 4: Effect of Biodiesel/Petroleum Diesel Blending on Density and Viscosity of Biodiesel.

\begin{tabular}{lcl}
\hline \multicolumn{3}{c}{ Density $\left(\mathbf{g} / \mathbf{c m}^{3}\right)$} \\
\hline Biodiesel Blends & $\mathbf{3 0}{ }^{\circ} \mathbf{C}$ & $\mathbf{4 0}{ }^{\circ} \mathbf{C}$ \\
\hline & & \\
PAOD 10:90 & $0.852 \pm 0.003$ & $0.851 \pm 0.000$ \\
PAOD 20:80 & $0.856 \pm 0.000$ & $0.852 \pm 0.001$ \\
PAOD 30:70 & $0.860 \pm 0.001$ & $0.858 \pm 0.001$ \\
PAOD 40:60 & $0.861 \pm 0.001$ & $0.857 \pm 0.001$ \\
DEOD 10:90 & $0.854 \pm 0.000$ & $0.851 \pm 0.000$ \\
DEOD20:80 & $0.851 \pm 0.002$ & $0.848 \pm 0.000$
\end{tabular}

$\begin{array}{lll}\text { DEOD30:70 } & 0.858 \pm 0.000 & 0.857 \pm 0.001 \\ \text { DEOD40:60 } & 0.860 \pm 0.001 & 0.856 \pm 0.0010 .880^{\mathrm{b}}\end{array}$

\section{Viscosity $\left(\mathrm{mm}^{2} / \mathrm{s}\right)$}

\begin{tabular}{lll}
\hline PAOD 10:90 & $4.152 \pm 0.317$ & $2.366 \pm 0.048$ \\
PAOD 20:80 & $4.344 \pm 0.062$ & $3.515 \pm 0.078$
\end{tabular}




$\begin{array}{lll}\text { PAOD 30:70 } & 4.570 \pm 0.028 & 3.351 \pm 0.035 \\ \text { PAOD 40:60 } & 4.810 \pm 0.057 & 3.270 \pm 0.028 \\ \text { DEOD 10:90 } & 4.350 \pm 0.335 & 3.260 \pm 0.085 \\ \text { DEOD 20:80 } & 4.440 \pm 0.028 & 3.420 \pm 0.140 \\ \text { DEOD 30:70 } & 4.850 \pm 0.002 & 3.645 \pm 0.120 \\ \text { DEOD 40:60 } & 5.885 \pm 0.588 & 4.325 \pm 0.0351 .9-6.0^{\mathrm{b}}\end{array}$

This experiment was limited to PAOD and DEOD biodiesels due to the reason already provided earlier. It was observed from Table 4 that for the entire ratio investigated, the biodiesel density was positively improved upon. For example at 30 ${ }^{\circ} \mathrm{C}$, PAOD density decreased from 1.105 (Table 3 ) to $0.852 \mathrm{~g} / \mathrm{cm}^{3}$ at the blend ratio 10:90 (Table 4). Similarly, DEOD density decreased from 0.860 (Table 3 ) to $0.854 \mathrm{~g} / \mathrm{cm}^{3}$ at the blend ratio 10:90 (Table 4). Thus, the density values obtained for the biodiesel and their blends fell within the recommended specified limits of $875-900 \mathrm{~kg} / \mathrm{m}^{3}$ [30] and 860 $900 \mathrm{~kg} / \mathrm{m}^{3}$ [32] for biodiesel fuels, and by other international standards [27]. Therefore, the biodiesels and their blends possessed the potentials that can be utilized as automobile diesel fuel and thus, reduce over dependence on the petroleum based diesel alone. Similarly, all the ratios gave an improved viscosity for the biodiesel/PBD blend. The obtained viscosity values fell within the ASTM $(1.9-6.0 \mathrm{~mm} 2 / \mathrm{s})$ and EN $\left(3.5-5.0 \mathrm{~mm}^{2} / \mathrm{s}\right)$ set standards, with biodiesel/PBD blend ratios 10:90 and 20:80 giving the best viscosity values that perfectly satisfied the fluidity requirements of an alternative biodiesel fuel. The improved viscosity and density values of the biodiesels due to their blend with PBD is summarized in Figure 4 below.

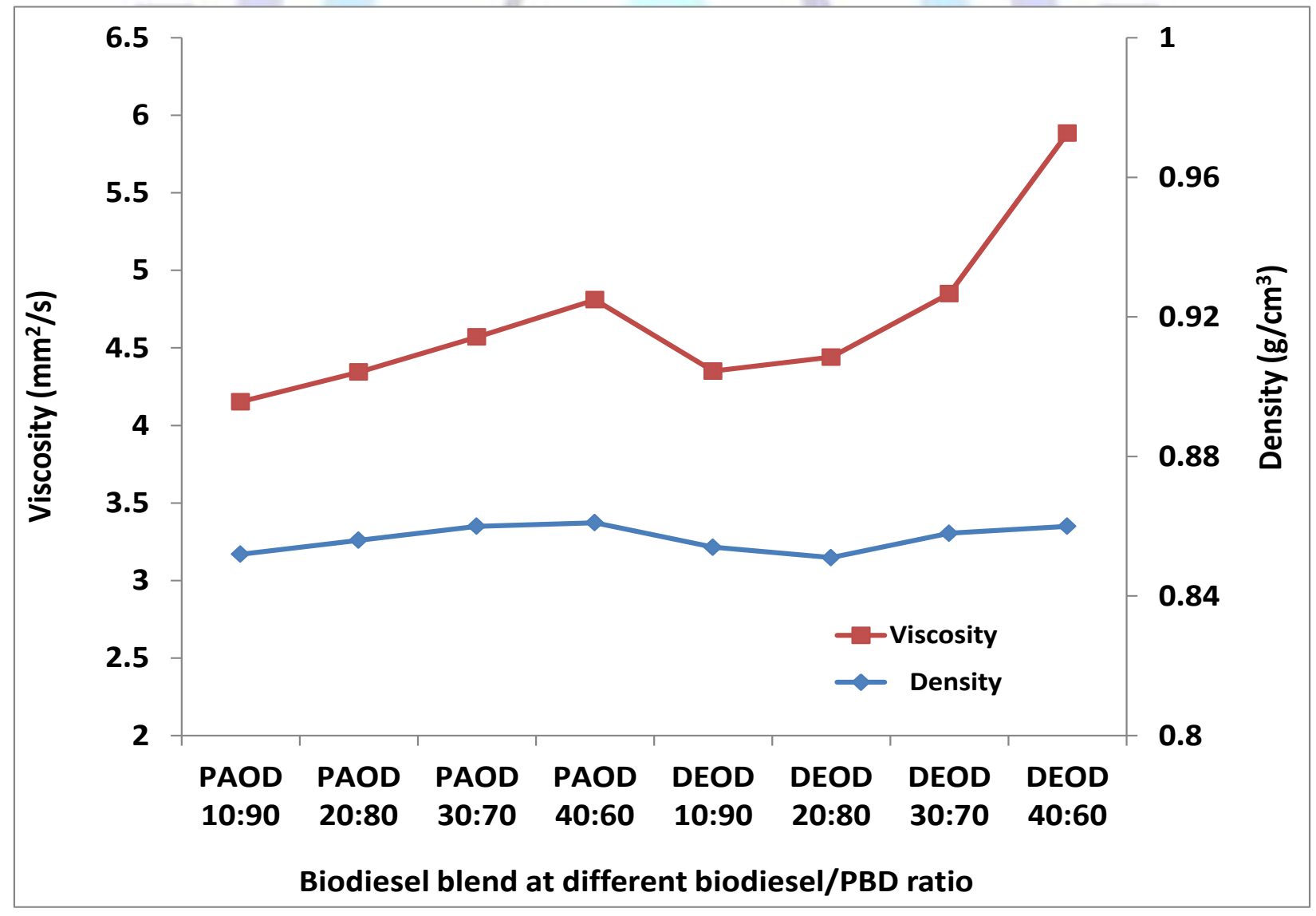

Figure 4: Density $\left(\mathrm{g} / \mathrm{cm}^{3}\right)$ and viscosity $\left(\mathrm{mm}^{2} / \mathrm{s}\right)$ values at $30{ }^{\circ} \mathrm{C}$ for biodiesel blend with petroleum-based diesel(PBD) at different biodiesel/PBD ratio.

\section{CONCLUSION}

It was established from this work that some non-conventional oils such as Irvingia gabonensis, Dacyodes edulis and Persea americana oils found in Ile-Ife, Nigeria are potential raw materials for the production of biodiesel based on their excellent percentage biodiesel yields which compared favourably with that of palm kernel oil biodiesel produced under the same conditions. Results obtained from this study indicated that Dacryodes edulis oil diesel (DEOD) and Persea Americana oil diesel (PAOD) had good biodiesel yields of $82 \%$ and $96 \%$ respectively. Their very good biodiesel qualities 
were supported by their fuel properties such as acid value, iodine value, pour point, cloud point, smoke and flash point that closely agreed with that of a commercially obtained petroleum-based diesel (PBD) investigated under the same experimental conditions, and with the international standards set for biofuels. Though, Irvingia gabonensis oil gave very high biodiesel yield (94\%), but its oil congealed readily at room temperature and its biodiesel application could be limited because of IGOD high cloud and pour points respectively. The oil can be further refined to remove gumming and unsaponifiable materials so that its biofuel potential can be maximized. The results of DEOD and PAOD blend with PBD at different biodiesel/petroleum diesel ratios confirmed a significant improvement in their biodiesel properties, such as acid value, iodine value, pour point, cloud point, smoke point, flash point, density and viscosity respectively at every blend ratio investigated, with best results obtained mostly at 30:70 and 40:60 biodiesel/PBD ratio. The production of biodiesel from these non-conventional oil sources could proffer solutions to several problems of non-renewability of petroleum resources and overdependence on petroleum based diesel. It is recommended that the non-conventional oilseeds should be investigated further for their full economic potentials.

\section{ACKNOWLEDGMENTS}

The authors acknowledge Obafemi Awolowo University (OAU) lle-lfe, Nigeria, for providing the research platform for this study.

\section{REFERENCES}

[1] Oghenejoboh, K.M., Babatunde, A.A. and Nwuaka, C.T. 2007. Effect of Air Pollution Arising from Associated Gas Flaring on the Economic Life of the People of Oil Producing Communities in Nigeria. Journal of Industrial Polluyion Control. 23 (1): 1-9

[2] McGovern, S. and Lee, C. K. 2008.Biofuel Economics, CO2 Balance and Energy Efficiency. Petroleum Technology Quarterly. Q3: 87-95.

[3] Oghenejoboh, K.M., Akhihiero, E.T. and Adiotomre, K.O. 2010.Viability of Biofuel as Alternative fuel in Nigeria's Transport System. International Journal of Engineering. $\quad 4$ (3): 445-453

[4] Rodrigues, S., Mazzone, I. C. A. and Santos, F. F. P. 2009. Optimisation of the Production of Ethyl Esters by Ultrasound Assisted Reaction of Soybean Oil and Ethanol. Brazilian Journal of Chemical Engineering. 26 (2):361-363.

[5] Mushrush, G., Beal, E.J., Spencer, G., Wynne, J.H., Lloyd, C.L., Hughes, J.M., Walls, C.L., \& Hardy, D.R. 2001. An Environmentally Benign Soybean Derived Fuel as a Blending Stock or Replacement for Home Heating Oil. Journal of Environmental Science and Health, Part A: Toxic/Hazardous Substances and Environmental Engineering. 36 (5): pp. 613-622, ISSN 1532-4117.

[6] Wardle, D.A. 2003. Global Sale of Green Air Travel Supported Using Biodiesel. Renewable and Sustainable Energy Reviews. 7 (1): pp. 1-64, ISSN 1364-0321.

[7] Batidzirai B., Faaij, A.P.C. and Smeets, E. 2006. Biomass and bioenergy supply from Mozambique. Energy for Sustainable Development. 10(1): 54-81.

[8] Alamu, O.J, Waheed, M.A. and Jekayinfa, S.O. 2007a. Biodiesel production from Nigerian Palmkernel oil: effect of $\mathrm{KOH}$ concentration on yield. Energy for Sustainable Development. 11(3): 77-82.

[9] Gupta, P.K., Kumar, R., Panesar, B.S. and Thapar, V.K. 2007. Parametric studies on bio-diesel prepared from rice bran oil. Agricultural Engineering International.Journal Sci. Res. Dev. 9: EE 06- 07.

[10] USEIA 2007. Energy Information Administration. World Proved Reserves of Oil and Natural Gas. Most Recent Estimates. www.eia.doe.gov (Last visited, June 2007).

[11] Petchmata, A., Yujatoen, D. and Shotipruk, A. 2008.Production of methyl esters From Palm Fatty Acids in Supercritical Methanol.Chiang Mai Journal of Science. 35: 23-25.

[12] Abigor, R.D., Uadia, P.O., Foglia, T.A. Haas, M. J., Jones, K.C., Okpala, E., Obibuzor, J.U. and Bafor, M.E. 2000. Lipase-Catalysed Production of Bio-diesel fuel from some Nigerian Lauric Oils. Biochemical Society Transactions. 28(6): $979-980$.

[13] Akanni, M.S., Oluyemi, E.O. and Adekunle, A.S. 2005. Physco-Chemical Properties of Some Non-conventional Seed Oils. Journal of Food Technology. 3(2): 177-181.

[14] American Oil Analytical Chemists (AOAC) 1990. Official Methods of the Association of Official Analytical Chemists. 15th Edition, 955 - 972.

[15] He, H., Wang, T. and Zhu, S. 2007. Continuous Production of Biodiesel Fuel from Vegetable Oil using Supercritical Methanol Process. The State Key Lab of Chemical Energy, Tsinghua University Beinjing, China.

[16] Foon, C.S., May, C.Y., Ngan, M.A. and Hock, C.C. 2004. Kinetic Study on Transesterification of Palm Oil. Journal of Oil Palm Research. 16(2): $19-25$.

[17] Addison, K. 2005. Make Your Own Biodiesel. http://www.journey-to forever.org/biodiesel making.httm. 
[18] Berchmans, B. J. and Hirata, S. 2008. Biodiesel Production from Crude JatrophaCurcas L. Seed Oil with a High Content of Free Fatty Acids.Bioresource Technology. 99: 1717.

[19] Salvatore, J.R. 2003. Land and Marine Diesel Fuels/Non-aviation Gas Turbines, In: Significance of Test for Petroleum Products. Available at http://www.books.google-com.ng/books. Page 72-79 (Last assessed 15 June, 2008).

[20] Ahmad, M., Rashid, S., Khan, M.A., Zafar, M., Sultan, S. and Gulzar, S. 2009.Optimisation of Base CatalysedTransesterification of Peanut Oil Biodiesel.African Journal of Biotechnology. 8 (3): 441-443.

[21] Mittelbach, M. and Schober, S. 2008. Bioscopes-Lot. 1c State of the Art of Biodiesel. Institute of Chemistry (IFC) Working Group for Renewable Resources, Karl-Franzens-University Graz A-8010 Graz Austria.

[22] Salles, K., Meneghetti, S.M.P., Ferreira de La Salles, W., Meneghetti, M.R., dos Santos, I.C.F., da Silva, J.P.V., de, Carvalho, S.H.V. and Soletti, J.I. 2010. Characterisation of Syagrus coronata (Mart.) Becc. Oil and Properties of Methyl Esters for Use as Biodiesel. Ind. Crop Prod. 32: 518-521.

[23] Chiu, C.W., Schumacher, L.G. and Suppes, G.J. 2004. Impact of Cold Flow Improvers on Soybean Biodiesel Blend. Biomass Bioenergy. 27: 485-491.

[24] Barua, P.K. 2011. Biodiesel from Seeds of Jatropha Found in Assam, India. International Journal of Energy, Information and Communications. 2 (1): 60.

[25] Oghenejoboh, K.M. and Umukoro, P.O. 2011. Comparative Analysis of Fuel Characteristics of Bio-Diesel Produced from Selected Oil-Bearing Seeds in Nigeria. European Journal of Scientific Research 58 (2): 238-246.

[26] Ajav, E.A. and Akingbehin, A.O. 2002. A Study of Some Fuel Properties of Local Ethanol Blended with Diesel Fuel. Agric. Eng. Int., CIGR Journal of Scientific Research and Development.IV: Manuscript EE 01003.

[27] Agarry, S.E., Ajani, A.O., Aworanti, A.O. and Solomon, B.O. 2010. Alkali-Catalysed Production of Biodiesel Fuel from Nigerian Citrus Seeds Oil.Proceedings of Conference of Nigerian Society of Chemical Engineers.40: 145-154.

[28] American Society of Testing and Materials (ASTM) 2008. ASTM D975 Requirements for Biodiesel . ASTM, Eaton, Maryland, USA.

[29] Demirbas, A. 2005. Biodiesel production from vegetable oils via catalytic and non-catalytic supercritical methanol transesterification methods.Progress in Energy and Combustion Science.31 (5-6): pp. 466-487, ISSN 0360-1285.

[30] American Society of Testing and Materials (ASTM) 2008. ASTM D6751-02 Requirements for Biodiesel . ASTM, Eaton, Maryland, USA.

[31] Adebayo, G.B., Ameen, O.M. and Abass, L.T. 2011. Physico-Chemical Properties of Biodiesel Produced from JatrophaCurcas Oil and Fossil Diesel. Journal of Microbiology and Biotechnology Research. 1 (1): 15.

[32] EN14214 2003. Automotive Fuels-fatty Acid Methyl Esters (FAME) for Diesel Engines Requirements and Test Methods. Berlin, Germany: Beuth-Verlag. 